\title{
A Influência de Liebman no Direito Processual Civil Brasileiro.
}

\author{
Alfredo Buzaid \\ Professor Catedrático da Faculdade de Direito da \\ Universidade de São Paulo
}

Capítulo I.

O Homem.

Sumário: 1. O intuito deste ensaio. 2. A vinda do Mestre ao Brasil. 3. Os primeiros discípulos de São Paulo. 4. Os processualistas do Rio de Janeiro. 5. As dificuldades iniciais do professor.

1. Ao escrever este breve ensaio sobre $A$ Influência de Liebman no Direito Processual Civil Brasileiro, não intento fazer um panegírico, de que o Mestre não necessita e que poderia ofender-lhe a modéstia, menos ainda compor um juízo crítico de sua obra, para o qual não me sinto habilitado, nem a publicação onde se inserirá este trabalho seria o lugar adequado. Aspiro tão só a oferecer um depoimento vivo, sincero e cheio de afeto do discípulo, que testemunha a saudade que ficou depois de seu regresso para a Itália e o reconhecimento imperecível pelo magistério que exerceu durante seis anos na Faculdade de Direito da Universidade de São Paulo. Estas páginas traduzem, pois, o penhor da eterna amizade, que se cultiva há mais de trinta anos.

A vida de EnRICo Tullio Liebman, conquanto tivesse sido curta a sua permanência entre nós, incorpora-se definitivamente na história do direito processual civil brasileiro como um marco fundamental, como um apostolado da ciência, como um templo do saber. Antes dele houve grandes processualistas, mas não houve escola; depois dele houve escola, no seio da qual floresceram grandes processualistas. Ele foi um divisor que, pondo remate a certo estilo de atividade processual, inaugurou entre nós o método científico, que os seus discípulos abraçaram apaixonadamente. 
2. Foi ao início da Segunda Guerra Mundial que aportou ao Brasil ENRICo TULLIo LIEBMAN, professor catedrático já aureolado ${ }^{1}$. Regeu, a princípio e por pouco tempo, um curso na Faculdade de Direito da Universidade de Minas Gerais. Depois transferiu sua residência para São Paulo, onde foi contratado para ministrar o curso de extensão universitária na Faculdade de Direito, aí permanecendo até 1946. Neste ano regressa à Itália. A sua Pátria, finda a guerra, reclamava-lhe a volta, a fim de assumir a cátedra da Faculdade de Direito da Universidade de Milão.

Começam então os preparativos da viagem entre os olhares tristes e lamentosos dos discípulos, que anteviam a hora de dar o adeus ao Mestre. Surgem os primeiros acenos da saudade, antecipando a melancolia, por já não poderem reunir-se com - Mestre, como fizeram anos seguidos, em sua casa, todos os sábados. Era aí, nesse íntimo convívio, que propunham questões, explanavam temas fundamentais e ouviam as sábias lições.

3. As aulas do Mestre, no curso de extensão universitária, proferidas primeiro em italiano e logo mais em português, eram concorridas. Dos que o assistiram com rigorosa assiduidade, fazendo constantemente perguntas ao Mestre, alguns tiveram a fortuna de freqüentar a sua casa, onde foram recebidos com a maior cordialidade. Participaram desse grupo Luís EULÁlIO DE BUENo VIDIGAL, o primeiro dentre os nossos já livre-docente e depois professor catedrático; BENVINDo AIRES, que domina latim e grego, além de várias línguas vivas, inclusive alemão; BRUNO AFFONSO DE ANDRÉ, inteligência penetrante, que exercia a função de juiz e já hoje está no ápice de sua carreira como Desembargador do Tribunal de Justiça; Jost́ FREDERICo MARQUES, também magistrado e mais tarde professor catedrático da Faculdade de Direito da Pontifícia Universidade Católica de São Paulo, autor de obras fundamentais; e, finalmente, quem escreve estas memórias, àquele tempo cultor da ciência do processo e preparando o seu concurso à docência na Faculdade de Direito da Universidade de São Paulo. Sentados junto a uma mesa comprida, em cujo centro ficava o Mestre, enliçavam-se nas prolongadas tertúlias, para as quais vinham já preparados após uma semana de largas meditações.

1. Enrico Tulio Liebman, Efficacia ed Autoritd della Sentenza, posta em vernáculo por ALFredo Buzaid e Benvindo AIREs, Ed. Forense, Rio de Janeiro, 1945; Le Opposizioni di Merito nel Processo d'Ésecuzione, trad. bras. de J. Guimarães Menegale, Ed. Saraiva, São Paulo, 1952. 
4. Outro centro de estudos processuais situava-se no Rio de Janeiro. Na curta permanência nesta cidade, que era a Capital da República, conheceu o Mestre, entre outros, dois notáveis processualistas: Lufs MACHAdo GUIMARÃEs e ElIÉZER RosA. Inteligências privilegiadas, imensa cultura e curiosidade insaciável, ambos se dedicavam empenhadamente ao estudo do direito processual civil. MACHADO GUIMARÃES escreve uma tese sobre A Instância e a Relação Processual (Rio, 1939), com a qual alcança a docência livre na Faculdade de Direito da Universidade do Rio de Janeiro, não prosseguindo em sua carreira por motivo de saúde. EliÉzer ROSA é um místico do direito processual civil, dividindo a sua evangelização entre o culto da ciência e a devoção de um crente. MACHADo GuIMARÃEs mais reflete do que escreve e viveu sempre torturado pelas mais requintadas meditações. Seus livros saíram a lume graças ao zelo de amigos e discípulos 2. ELIEZER ROSA criou vários cursos no Rio de Janeiro e, sendo expositor diserto e vestindo os seus pensamentos com louçanias de estilo clássico, transmitiu aos seus alunos jóias de alto saber. É um autêntico espadachim. Em defesa dos princípios fundamentais da ciência sai a combate em livros, artigos e conferências, criticando com ardor e veemência ${ }^{3}$.

Do grupo do Rio de Janeiro fazia parte também Luís ANTÔNIO DE ANDRADE, que colaborou com MACHADo GUIMARÃES nos Comentários ao Código de Processo Civil ${ }^{4}$. Ingressou na magistratura, sendo Desembargador no Tribunal de Justiça do Estado do Rio de Janeiro, onde ocupou a presidência. Este eminente jurista prestou a mais valiosa contribuição para a revisão do projeto, que veio a converter-se no Código de Processo Civil vigente.

5. EnRICo Tullio Liebman foi professor no sentido mais completo da palavra. Os parcos vencimentos do magistério eram assaz insuficientes para atender às condições normais de sub-

2. Além da obra já citada no texto, escreveu parte dos Comentários ao Código de Processo Civil. Ed. Forense, v. IV, Rio de Janeiro, 1942; Carência

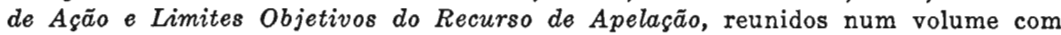
apresentação de Oto Gil e carta de Eliezer Rosa, Rio de Janeiro, 1962; e Estudos de Direito Processual Civil, Rio de Janeiro-São Paulo, 1969, 336 páginas.

3. Eliezer Rosa publicou: Dicionário de Processo Civil, Ed. de Direito, 1957, Rio de Janeiro, com extenso prólogo; Leituras de Processo Civil, Guanabara, 1970 .

4. Luís Machado Guimarães, Comentários ao Código de Processo Civil, v. IV, nota prévia. 
sistência. Vieram-lhe em socorro os direitos autorais devidos pela publicação das Instituições de CHIOVENDA e da edição brasileira dos Embargos do Executado e da Eficácia e Autoridade da Sentença.

De uma feita, convidado a integrar um escritório de advocacia com o encargo único de arrazoar causas e recursos, declinou amavelmente o obséquio sob a alegação de que, num país que o recebeu com tanta hospitalidade, não podia fazer concorrência aos profissionais que militavam no foro. Sugeriu-se-lhe então que desse pareceres. Com verdadeiro custo aceitou a idéia e passou a escrevê-los ${ }^{5}$. Os pareceres são lições de notável cultura e saber, em que o Mestre provou que dominava com absoluta segurança assim o direito positivo vigente, como toda a doutrina anterior, nomeadamente o direito lusitano.

Mas, em verdade, o que lhe aprazia não era tanto esse gênero lucrativo de atividade intelectual quanto o estudo desinteressado das instituições processuais, para cuja exegese contribuiu sem rival. Os mais brilhantes ensaios foram redigidos pelo Mestre com aquele mesmo descortino, cabedal de saber e agudeza de penetração que caracterizaram as obras editadas na Itália.

Esse é o homem.

\section{Capítulo II.}

\section{o Labor Científico.}

SUMÁRIo: 6. A atividade intelectual. 7. A exegese do Código de Processo Civil.

6. O labor intelectual do Mestre se desenvolve na cátedra, nos livros, nas conferências, nos artigos de doutrina e nos comentários a arestos dos tribunais. É verdadeiramente difícil dizer qual dos seus escritos sobreexcede os demais. Em qualquer deles há sempre uma idéia nova e valiosa para a interpretação do direito nacional, elaborada segundo o rigor dos princípios científicos. O leitor pode preferir um a outro trabalho conforme suas inclinações pessoais. Mas todos têm,

5. Vejam-se alguns pareceres reunidos e publicados nos Estudos sobre? Processo Civil Brasileiro, $2{ }^{\mathrm{a}}$ ed., com notas de Ada Pelegrini Grinover, José Bushatsky Ed., p. 83 e segs.; 179 e segs.. 
quanto à substância, a mesma erudição e, quanto à forma, o mesmo rigor, clareza e elegância de linguagem cristalina.

Dentre as obras que publicou, convém começar pelas Instituições de CHIOVENDA, que adaptou ao direito brasileiro com notas de altíssimo valor. Tendo entrado em vigor em 1940 o Código de Processo Civil, baixado pelo Decreto-lei n. ${ }^{\circ}$ 1.608 , de 18 de setembro de 1939, ocupa-se LIEBMAN, desde logo, em interpretá-lo; ocorre-lhe a feliz idéia de mandar traduzir as Instituições de CHIOvENDA, apondo-lhes notas com remissões ao direito brasileiro. As notas variam de extensão. Umas são de mera correspondência entre o direito italiano e o direito brasileiro; outras, porém, são verdadeiros estudos sobre as instituiçôes processuais, com larga investigação histórica e ricas fontes de direito comparado. Há notas que exaurem o tema em toda a plenitude ${ }^{6}$

Em 1945 sai a lume, posta em vernáculo, a monografia intitulada Eficácia e Autoridade da Sentença. Conquanto seja obra eminentemente doutrinária, enriqueceu-a o Mestre com um prólogo e notas de acomodação ao direito brasileiro, além de incluir outros ensaios ${ }^{7}$. Em 1947 reúne os seus artigos, conferências, pareceres e comentários a acórdãos no volume designado por Estudos sobre o Processo Civil Brasileiro. E, em 1952, obedecendo ao método adotado em Eficácia e Autoridade da Sentença, publica os Embargos do Executado.

7 Esta produção do Mestre, durante o quinqüênio de sua permanência no Brasil, com ser quantitativamente satisfatória, teve o mérito de fixar em base definitiva a doutrina do Código de 1939. O Mestre trabalhava de modo paciente e tranqüilo. Não tinha pressa de escrever, nem escrevia coisas apressadas. Tudo que lhe saía da pena tinha a força e o esplendor de um estudo profundamente meditado. Ele falava, como escrevia, de modo claro, vigoroso e persuasivo. Ninguém o via titubear; tinha sempre a segurança do sábio, que transmite a beleza dos seus pensamentos sem ostentação. $O$ fascínio do seu magistério estava na simplicidade de sua exposição, na elegância do seu estilo e na forma sentenciosa dos seus conceitos.

6. Sobre as notas de LIEBMAN, ver Alfredo BuzAid, introdução às Institui̧̧ões de Direito Processual Civil de Chrovenda, $2 .^{\mathrm{a}}$ ed., Saraiva, Ed., 1965, v. I, p. VII e seg.

7. Enrico Tullio Liebman, Eficácia e Autoridade da Sentença, p. 141 e segs. 
Capítulo III.

\title{
A Repercussão das Idéias de Liebman no Código de Processo Civil Vigente.
}

\author{
$\S 10^{\circ}$
}

\section{Considerações Gerais.}

\begin{abstract}
SUMÁrIo: 8. A influência de Liebman no plano dos conceitos e no plano da política legislativa. 9. A ação como categoria autônoma e as ações especiais. 10. Classificação das ações especiais.
\end{abstract}

8. A influência das idéias de LIEBman há de ser considerada no plano dos conceitos e no plano da política legislativa. A análise do primeiro requer uma apreciação geral das suas idéias, da sua doutrina, do seu pensamento no direito processual civil contemporâneo. 0 estudo do segundo dá uma clara perspectiva da repercussão do seu sistema no Código de Processo Civil, que o acolheu em suas linhas básicas, mantendo-lhe a unidade fundamental.

O Código de Processo Civil compõe-se de cinco livros, sendo a matéria distribuída da seguinte forma: Livro I do processo de conhecimento; Livro II - do processo de execução; Livro III - do processo cautelar; Livro IV - dos procedimentos especiais, classificados em duas espécies procedimentos de jurisdicão contenciosa e procedimentos de jurisdição voluntária; Livro $\mathrm{V}$ - das disposições finais $e$ transitórias. Para a verificação das idéias do Mestre, que o Código de Processo Civil consagrou, basta que as observações se cinjam aos três primeiros livros, não havendo mister detido exame do livro IV, no qual a sua influência opera por repercussão. Este livro cuida de procedimentos especiais, a que correspondem ações geralmente nominadas.

9. Esta solução de política legislativa não se divorcia da doutrina, que proclama a autonomia da ação, isolando-a do direito subjetivo. Considerada em sua natureza, a ação é uma categoria jurídica autônoma ${ }^{8}$. Mas uma coisa é o conceito de acão; outra e bem distinta é a acão especial, típica, nominada. Encuanto aquela tem três condicões, que são necessárias e suficientes para a sua admissibilidade, estas têm condições

8. Liebman, Problemi del Processo Civile, p. 43 e segs. 
próprias, que visam a individuá-las, sem prejuízo das outras condições, que caracterizam a ação. As ações especiais são, pois, dotadas de um plus, que serve para lhes dar a conotação adequada em correspondência com o tipo de direito material que a ordem jurídica positiva estabelece. Em outras palavras, a ação é o poder jurídico de invocar a prestação jurisdicional. As ações especiais, sobre terem tal poder, qualificam-se, entretanto, por requisitos específicos em consideração do fim a que estão preordenadas.

Este fato não desnatura o caráter abstrato da ação. Quando por exemplo, o Código de Processo Civil estatui que "a ação de prestação de contas competirá a quem tiver o direito de exigi-las ou a obrigação de prestá-las" (art. 914), esta afirmação não subentende o dualismo - direito subjetivo e ação, devendo reputar-se a expressão legal "direito de exigi-las" não como grau de subordinação à relação jurídica material, mas como critério de determinação da legitimidade ativa e passiva ${ }^{\circ}$.

10. Por outro lado, não podia o Código omitir a clássica divisão das ações em pessoais e reais, mobiliárias e imobiliárias, petitórias e possessórias e muitas outras, cujos bons resultados a doutrina há longo tempo proclama ${ }^{10}$. A menção dessas espécies de ações típicas e nominadas obedece aos imperativos da realidade e tem o mérito de atender a uma tradição duas vezes milenária, indicando não tanto a preexistência do direito deduzido em juizo quanto a espécie da matéria sobre que se controverte. A inclusão delas, no Livro IV, não se funda, portanto, senão na necessidade de lhes estabelecer procedimento especial, dadas as peculiaridades que as qualificam, algumas em seu momento inicial (ex. possessórias), outras em todo o desenvolvimento da relação processual (ex. divisórias e demarcatórias) e. finalmente, outras pela finalidade a que se propõem (ex. inventário de bens do falecido). o legislador de 1973 colheu a este respeito os melhores subsídios da doutrina moderna e reduziu ao mínimo indispensável as chamadas ações de procedimento especial.

9. Não procede, pois, a crítica feita por Celso Agrícola Barbi que, invocando a redação do art. 914 do Código de Processo Civil, vê aí uma contradição com a doutrina abstrata da ação, abraçada pelo Código de Processo Civil (Cf. Celso Agrícola Barbi, Comentário ao Código de Processo Civil. Forense, 1975 , v. I, p. 44).

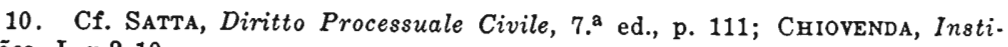
tuigões, I, n. 10 . 
Por considerações peculiares ao direito brasileiro, foram incluídos no Livro IV os procedimentos de jurisdição voluntária. Era livre o legislador de tratar esta matéria, ou reunindo no Código tais procedimentos, ou ordenando-os em lei especial. Optou pela primeira solução não só para ser fiel à tradição, como também porque, correndo perante órgãos do Poder Judiciário, não se justificava politicamente a separação.

Dito já o essencial à guisa de considerações gerais, cabe-nos agora descer à análise da influência de LIEBMAN no plano dos conceitos fundamentais.

\section{$\S 2 .^{\circ}$}

\section{Da Ação e Das Condições de Sua Admissibilidade.}

SUMÁrio: 11. Conceito de ação. Doutrinas fundamentais. 12. Condiçōes de admissibilidade da ação. 13. O Código de Processo Civil vigente consagra a doutrina de Liebman.

11. O conceito de ação, tema tormentoso do direito processual civil, levou LIEBMAN às mais profundas meditações, enquanto permaneceu na América; foi nestas terras que escreveu Concepto de la Acción Civil ${ }^{11}$ e o seu famoso estudo sobre $O$ Despacho Saneador e o Julgamento do Mérito ${ }^{12}$, que preparam o seu ensaio fundamental sobre $L$ 'Azione nel sistema del Diritto Processuale Civile" ${ }^{13}$. A esse tempo eram bem conhecidas as correntes principais, que procuravam explicar a natureza jurídica da ação. Uma a considerava direito concreto, que se resolve no direito a obter do Poder Judiciário uma sentença favoravel ${ }^{14}$. Partidário desta teoria, deu-lhe CHIOVENDA conotação original, não só ao considerar a ação um direito potestativo, como também por sustentar que objeto do processo é a vontade concreta da lei, cuja afirmação e atuação se reclamam, assim como 0 próprio poder de reclamar-lhe a atuação, isto é, a ação ${ }^{15}$.

11. Liebman, Concepto de la Accion Civil, em "Revista de Estudios Juridicos y Sociales", Ano XIII, Montevideo, 1940, p. 217 e segs.

12. Liebman, Estudos sobre o Processo Civil Brasileiro, Saraiva \& Cia., São Paulo, 1947, p. 107 e segs.; 2. ${ }^{\text {a }}$ ed., com notas de Ada Pelegrini Grinover, p. 97 e segs.

13. Liebman, Problemi del Processo Civile, p. 22 e segs..

14. Cf. WACH, Handbūch, I, p. 19.

15. ChIovenda, Instituicões, v. I, n. ${ }^{\circ}$ s 6 e 15. 
A outra doutrina é a da ação havida como direito abstrato; esta doutrina tem cambiantes vários, desde a posição extremada daqueles autores que reputam a ação direito de obter a prestação jurisdicional, desprovida de qualquer condição ${ }^{16}$, até os moderados, que lhe põem condições subjetivas e objetivas de admissibilidade ${ }^{17}$. Desta corrente intermédia um dos processualistas mais notáveis é LIEBMAN, para quem a ação é direito subjetivo processual, não direito subjetivo material. Por isso lhe corresponde não uma obrigação, mas o exercício de uma função por parte de órgão do Estado e uma sujeição por parte do adversário, que não pode evitar os efeitos da ação ${ }^{18}$.

12. A doutrina do direito concreto e a doutrina do direito abstrato na modalidade construída por LIEBMAN, admitem condições da ação. Mas enquanto para a primeira as condições da ação são a existência do direito, a legitimidade e 0 interesse ${ }^{19}$, já para a segunda a primeira condição (existência do direito) é substituída pela possibilidade jurídica, entendida como a possibilidade para o juiz, na ordem jurídica a que pertence, de pronunciar a espécie de decisão requerida pelo autor ${ }^{20}$. Não é essa, porém, a única distinção. Outra, da maior relevância, consiste em demonstrar que o material do processo se projeta num trinômio: pressupostos processuais, condições de ação e lide ${ }^{21}$.

A possibilidade jurídica supõe, assim, na ordem jurídica positiva, a existência do tipo de providência, tal como fora pedida pelo autor. A idéia tem a sua correspondência na doutrina do direito concreto. "Se la norma", escreve CHIovendA, "a cui l'attore si riferisce non esiste come norma astratta, è vano ricercare se sia divenuta concreta; la domanda è infondata" ${ }^{22}$. Não é outro o sentir de CALAMANDREI, que reconhece e proclama a justeza do conceito de CHIovenda, porque, "se l'attore afferma un fatto e da esso vuol dedurre una conseguenza giuridica, che, ove anche il fatto fosse vero,

16. Degenkolb, Einlassugszwang, p. 1 e segs.; Rocco, Sentenza Civile, p. 80 e segs.

17 Liebman, Estudos sobre o Processo Civil Brasileiro, 2. ${ }^{\mathrm{a}}$ ed., p. 129.

18. Liebman, Estudos, $2 .^{\mathbf{a}}$ ed., p. 130 , nota 30 .

19. ChIOVENDA, Instituições, v. I, n. ${ }^{\circ}$ s 38 usque 40.

20. LIEBMAN, Estudos, cit. p. 124.

21. LieBMAN, Estudos, cit. p. 122.

22. ChIovenda, Principii di Diritto Processuale Civile, 3. ${ }^{\mathrm{a}}$ ed., p. 150; Instituições, v. I, n. ${ }^{\circ} 38$. 
non ne deriverebbe; o se, ipotesi più difficile ma più evidente, l'attore pretende un effetto che giuridicamente non può nel vigente sistema legislativo da nessun fatto nascere (p. e. se l'attore chiedesse la morte del convenuto), - in simili casi sarebbe perfettamente inutile che il giudice, prima di decidere il problema di diritto, sprecasse il tempo ad indagare se il fatto è vero, quando anche una risposta positiva a simile indagini porterebbe senza dubbio a una risposta negativa al susseguente problema di diritto" ${ }^{23}$. No sistema de LIEBMAN, não se diz que a ação é infundada, mas sim que o autor dela é carecedor, porque não há na ordem jurídica positiva o tipo de providência jurisdicional requerido pelo autor.

13. O Código de Processo Civil vigente perfilha a doutrina de LIEBMAN. Na verdade, o processo se extingue com julgamento do mérito (art. 269), ou sem julgamento do mérito (art. 267). Dentre os casos em que o processo se extingue sem julgamento do mérito, inclui o Código o de n. ${ }^{\circ}$ VI, que se expressa nos seguintes termos: "quando não concorrer qualquer das condições da ação, como a possibilidade jurídica, a legitimidade das partes e o interesse processual".

Eis aí as três condições de admissibilidade da ação, cujo concurso é indispensável para que o juiz conheça do mérito da causa. O mérito da causa é propriamente a lide, a que o Código dedica um artigo assim enunciado: "Art. 128. O juiz decidirá a lide nos limites em que foi proposta sendo-lhe defeso conhecer de questões, não suscitadas, a cujo respeito a lei exige a iniciativa da parte". A lide é aí o conflito real ou virtual de interesses, exposto pelo autor na petição inicial, a que o juiz deve dar uma resposta ${ }^{24}$, ouvindo-se as alegações do réu, a quem é assegurada a possibilidade de deduzir no processo as razões que tiver para impugnar o pedido.

Em estreita correspondência com o conceito de ação está o de jurisdição. Sendo a jurisdição a atividade do Poder Judiciário destinada a atuar a vontade concreta da lei nos casos e formas legais, conforme as disposições que o Código estabelece (art. $1 .^{\circ}$ ), só quando o magistrado decide a lide é que se configura, em toda plenitude, ato declaradamente jurisdicional no sentido mais próprio e restrito. Todas as outras decisões têm caráter preparatório e auxiliar, não só as que conhecem dos pressupostos processuais, como também as que conhecem

23. Calamandrei, Studi sul Processo Civile, v. I, p. 9.

24. LIEBMan, Estudos cit., p. 122; RoSenBerg, Lehrbuch, 8. ${ }^{\text {a }}$ ed., p. 397. 
das condições da ação e que, portanto, verificam se a lide, pela concorrência dos requisitos prévios, pode .ser julgada. Recusar-lhe o julgamento ou reconhecê-lo possível não é ainda propriamente julgar; é atividade que por si nada tem de jurisdicional e adquire esse caráter só por ser uma premissa necessária para o exercício da verdadeira jurisdição ${ }^{25}$.

\section{$\S 30^{\circ}$}

\section{Da Execução.}

SUMÁRIo: 14. Execução fundada em título judicial e ação executiva fundada em título extrajudicial. 15. A nova denominação. 16. A unificação dos títulos executivos.

14. Até o advento do Código de Processo Civil de 1973 conheceu o direito brasileiro dois meios de realizar a função executiva: a) pela parata executio, quando o título era judicial; b) pela ação executiva, quando o título era extrajudicial. A um simples relance de olhos bem se vê que as condições de admissibilidade de uma via e de outra eram distintas, posto que ambas tendessem, através de um conjunto de atos executivos, à satisfação do credor. Mas, como observa LIEBMAN, diferentes foram os resultados da evolução histórica nos países do continente europeu. O direito costumeiro francês reafirmou energicamente a equivalência das sentenças e dos instrumentos públicos (lettres obligatoires faites par devant notaire ou passées sous seel royal) e reconheceu a ambos a exécution parée. Este princípio foi acolhido pelas Ordenações reais e depois pelo Code de Procédure Civil napoleônico de 1806, do qual passou para a maior parte das legislações modernas ${ }^{26}$. Efetivamente adotaram, nos nossos dias, o sistema unificado os Códigos de Processo Civil da Itália (art. 474), da Alemanha ( $\$ 704$ e 794), de Portugal (art. 46) e a Lei de Execuções da Áustria $\left(\S 1^{\circ}{ }^{\circ}\right)$.

15. Esse dualismo do direito brasileiro levou o Mestre a designar a ação, fundada em título extrajudicial, de ação executiva, como tradicionalmente era conhecida e a ação, fundada em sentença condenatória, de ação executória, que corresponde à execução propriamente dita ${ }^{27}$. Promovia-se a

25. LiEbman, Estudos cit., p. 128.

26. Liebman, Processo de Execução, n. ${ }^{\circ}$ 6, nota 10.

27. LIEBman, Estudos cit., p. 49; em ChIOvENDA, Instituiçōes, v. I, n. ${ }^{\circ} 88$, nota 17 . 
execução forçada, portanto, através de duas ações, que se iniciavam pela penhora, mas tinham desenvolvimento ulterior distinto. A ação executiva, se contestada, seguia o procedimento ordinário, sendo assegurada ampla defesa ao réu e devendo realizar-se a audiência de instrução e julgamento como ato essencial de validade da relação jurídica processual. 0 Código de 1939, quanto à ação executória, limitava, ao contrário, o direito de impugnação às matérias taxativamente enunciadas no art. 1.010. Se o executado oferecesse embargos, abria-se um incidente de mérito que, conforme a sentença que fosse proferida, ou autorizava a execução a retomar o seu curso ou lhe punha termo.

16. Graças ao magnífico trabalho de LiEBmaN - que analisa a execução desde a actio iudicati romana até o direito intermédio, o nascimento dos instrumenta guarentigiata na Idade Média, a evolução da tutela dos títulos executivos judiciais e extrajudiciais, públicos e particulares no direito europeu continental e no direito brasileiro e a necessidade de dar tratamento sistemático a institutos tão importantes, - legislador brasileiro, que elaborou o Código de Processo Civil de 1973, era livre de adotar a política de unificação dos títulos executivos ou de manter o dualismo das ações. O Código segue a primeira orientação porque, na verdade, a ação executiva nada mais é do que uma espécie da execução geral; e por isso reúne os títulos judiciais e extrajudiciais, dando-lhes tratamento unitário. Nenhuma razão científica aconselhava a manter o dualismo e preponderantes razões de ordem prática recomendavam a supressão de ações especiais, já considerável e desnecessariamente multiplicadas no direito nacional.

$$
\S 4 .^{\circ}
$$

\title{
Do Processo Cautelar.
}

\author{
Sumário: 17. Função preventiva e ação cautelar. 18. Poder \\ acautelatório do juiz. 19. Disciplina jurídica do processo \\ cautelar.
}

17. Entre os bons resultados obtidos pela revisão de conceitos no direito processual civil está a nova doutrina das medidas cautelares. O Código de Processo Civil brasileiro de 1939 incluiu-as no Livro V como medidas preventivas sob a epígrafe de processos acessórios (art. 675 e segs.). Sob este aspecto manteve a tradição do Regulamento $\mathrm{n} .^{\circ} 737$, de 1850 
(parte I, titulo VII), que os Códigos estaduais, no regime do pluralismo legislativo, se limitaram a reproduzir.

Durante esse longo período, a idéia preponderante, na conceituação dessas medidas era a assessoriedade do processo preparatório preventivo ou incidente, posto em confronto com o processo principal. Tal modo de ver correspondia àquele tempo ao conceito civilístico da ação e retardou o acolhimento das novas idéias que isolaram a medida cautelar, erigindo-a à categoria de ação autônoma consoante a função preventiva do processo. LIEBMAN ressaltou a doutrina moderna, observando: "O processo acautelatório tem, de fato, como organismo processual, uma individualidade própria: uma demanda, uma relação processual, um provimento final, um objeto próprio, que é a ação acautelatória" ${ }^{28}$. Na verdade, o poder jurídico de obter uma dessas medidas é, conforme a lição de CHIovenda, uma forma de ação, ação cautelar" ${ }^{29}$. É mera ação, prossegue o ilustre autor, que não se pode considerar como acessório do direito acautelado, porque existe como poder atual, quando ainda não se sabe se o direito acautelado existe ${ }^{30}$.

18. Por outro lado, como assinala o Mestre, "também na legislação brasileira omite-se atribuição expressa ao juiz de um poder acautelatório geral, de que ele se possa valer, segundo as necessidades e as circunstâncias fora dos casos tradicionais especialmente previstos" ${ }^{31}$. Assim falava sobre o Código de 1939. Mas, em seguida se esforçou por construir a doutrina do poder acautelatório geral, sugerindo: "Todavia, os termos do art. 675 e especialmente de seu $n .^{\circ}$ II são redigidos de modo tão amplo e genérico, que se pode dizer que, ao menos na pendência da lide, o juiz dispõe efetivamente desse poder geral" 32 .

A outorga ao juiz de um poder cautelar geral foi reconhecida amplamente pelo Código de Processo Civil de 1973, atendendo ao magistério de LIEBMAN. Fê-lo em três disposições legais. A primeira reza: "Art. 797. Só em casos excepcionais, expressamente autorizados por lei, determinará o juiz medidas cautelares sem a audiência das partes." A segunda estatui: "Art. 798. Além dos procedimentos cautelares específicos, que

28. Liebman, em Chiovenda, Instituif̧ões, v. I, n. ${ }^{\circ} 82$, nota 1 .

29. ChIOvendA, Instituicões, v. I, n. ${ }^{\circ} 82$.

30. Chiovenda, Institui६̧ões, v. I, n. ${ }^{\circ} 82$.

31. LiebMan, em CHIOvenda, Instituições, v. I, n. ${ }^{\circ} 84$, nota 10.

32. LIEBMAN, em CHIOveNDA, Instituições, v. I. n. ${ }^{\circ} 84$, nota 10. 
este Código regula no Capítulo II deste Livro, poderá o juiz determinar as medidas provisórias que julgar adequadas, quando houver fundado receio de que uma parte, antes do julgamento da lide, cause ao direito da outra lesão grave e de difícil reparação". E, finalmente, a terceira dispõe: "Art. 799. No caso do artigo anterior, poderá o juiz, para evitar o dano, autorizar ou vedar a prática de determinados atos, ordenar a guarda judicial de pessoas e depósito de bens e impor a prestação de caução". Tal é o poder cautelar geral, tendo o legislador brasileiro compreendido que, em circunstâncias especiais, poderá o juiz decretar de ofício medidas preventivas na pendência do processo.

19. O processo cautelar constitui objeto do Livro III, que está dividido em dois capítulos. O capítulo I contém disposições gerais, que regem, além do poder cautelar do juiz, o procedimento e a eficácia das medidas. O capítulo II abrange os procedimentos cautelares específicos, a saber: o arresto, o seqüestro, a caução, a busca e apreensão de pessoas e coisas, a exibição de coisas, documentos e escrituração comercial, a produção antecipada de provas, os alimentos provisionais, o arrolamento de bens, a justificação da existência de fato ou de relação jurídica, os protestos, notificações e interpelações, a homologação do penhor legal, a posse em nome do nascituro, o atentado, o protesto e a apreensão de títulos e outras medidas provisionais. Por consideraçóes peculiares à natureza de cada espécie, regulou o Código procedimento próprio. Mas, ao tratar de todas as espécies, deu-lhes caráter unitário e sistemático.

Fica concluída aqui a análise da influência de LIEBMAN no plano dos conceitos fundamentais. Importa agora entrar no estudo particular do seu pensamento em numerosas disposições especiais constantes do Código de Processo Civil vigente.

$$
\S 5 .^{\circ}
$$

\title{
Disposições Especiais do Código de Processo Civil.
}

\author{
SUMÁrio: 20. Ação declaratória e ação declaratoria incidental. \\ 21. Substituição processual. 22. O dever de lealdade pro- \\ cessual. 23. Ampliação dos poderes do juiz. 24. A direção \\ do processo. 25. Ato atentatório à dignidade da justiça. \\ 26. A revelia. 27. Escassez de normas sobre a revelia do \\ Código de 19s9. 28. Conceito de coisa julgada. 29. Limites \\ objetivos da coisa julgada.
}

20. A ação declaratória já estava regulada no Código de Processo Civil de 1939 (art. $2 .^{\circ}, \S 2 .^{\circ}$ ). Surgiu desde logo 
a conhecida controvérsia se, tendo o autor a possibilidade de intentar a ação condenatória, fica excluído o interesse para ajuizar a ação declaratória. No entender de LIEBMAN, ambas as ações concorrem, de sorte que, se o direito já tiver sido violado, nem por isso carece o autor de interesse processual para propor a ação declaratória, porque "quem afirma a ausência de interesse para a ação declaratória quando é proponível também a condenatória, introduz no art. $2^{\circ}$, parágrafo único do Código de Processo Civil uma limitação que aí não se contém (como se essa disposição estabelecesse que o interesse na simples declaração deve subsistir somente se nenhuma outra ação for proponível no caso concreto). O intérprete não pode restringir a ampla fórmula da lei" ${ }^{33}$. O legislador do Código de 1973, para pôir cobro a essa disputa, que empolgou juristas e tribunais, estatuiu no art. $4 .^{\circ}$, parágrafo único: "É admissível a ação declaratória, ainda que tenha ocorrido a violação do direito".

O Código de 1939 não continha nenhuma regra sobre a ação declaratória incidental. Mas o parágrafo único do art. 287, declarando que "considerar-se-ão decididas todas as questões que constituem premissa necessária da conclusão", poderia levar o intérprete a crer que a coisa julgada abrangeria também as questões prejudiciais. O princípio dominante a este respeito é que elas são julgadas, em regra, incidenter tantum e, por consegüinte, sem efeito de coisa julgada ${ }^{34}$. A nota de LIEBMAN tende a afastar a exegese, que amplia às questões prejudiciais a coisa julgada, por ser avessa à jurisprudência, à tradição do direito brasileiro e às mais importantes legislações modernas ${ }^{35}$. $\mathrm{O}$ direito europeu conhecia e já aplicava, com êxito, um instituto denominado ação declaratória incidental. Foi este instituto que o Código de Processo Civil de 1973, consagrou no art. $5 .^{\circ}$, ao prescrever: "Se, no curso do processo, se tornar litigiosa relação jurídica de cuja existência ou inexistência depender o julgamento da lide, qualquer das partes poderá requerer que o juiz a declare por sentença". E coerentemente com este enunciado estatuiu que não faz coisa julgada a apreciação da questão prejudicial, decidida incidentemente no processo (art. 469, III).

33. Liebman, em Chiovenda, Instituifõos, v. I, n. ${ }^{\circ} 66$, nota 8 .

34. Liebman, em Chiovenda, Instituiçōes, v. I, n. ${ }^{\circ} 124$, nota 6 .

35. Liebman, em ChIOvenda, Instituiçöes, v. I, n. ${ }^{\circ} 124$, nota 6 . 
21. No direito positivo nacional há várias disposições legais que indicam casos de substituição processual (Cf. Código Civil, arts. 289, 233 e 1.580, parágrafo único ; Código Comercial, art. 517). Mas no Código de Processo Civil faltava uma norma que explicitasse o conceito. LIEBMAN, comentando CHIOVENDA, diz que "a característica da substituição processual consiste em que uma pessoa (substituto) atua no processo por um direito alheio, mas no nome próprio, isto é, como verdadeira parte, distinguindo-se assim da figura muito mais conhecida do representante" ${ }^{36}$. Eis aí uma definição plenamente satisfatória do instituto. O Código de Processo Civil vigente não hesitou em adotá-la, estabelecendo no art. $60^{\circ}$ : "Ninguém poderá pleitear, em nome próprio, direito alheio, salvo quando autorizado por lei."

22. Desde o último quartel do século passado, sob a influência dos Códigos de Processo Civil da Àustria (§ 178) e da Alemanha $(\S 138)$, o problema da lealdade das partes ganha excepcional importância, dando origem à rica literatura. As partes servem-se do processo para conseguir a atuação da vontade concreta da lei. Ora não lhes é lícito agir em detrimento do processo, transformando-o em meio de fraude, de dolo ou de improbidade. Instituto de direito público, o processo se nobilita quando realiza o direito e se degrada quando passa a ser arma da alicantina. LIEBMAN assinala que "essa tendência das legislações mais recentes equivale a outra manifestação de abandono da concepção individualista do processo, substituída por uma concepção publicística, não hesitante em limitar a liberdade das partes em consideração ao princípio da conduta processual honesta e que, portanto, estabelece a obrigação de só se utilizar do processo para fins e com meios lícitos." 37 . O Código de Processo Civil vigente disciplina, em seções distintas, os deveres das partes e a sua responsabilidade por dano processual. $\mathrm{O}$ art. 14 impõe às partes e aos seus procuradores o dever de: I expor o fato em juízo conforme a verdade; II — proceder com lealdade e boa fé; III — não formular pretensões, nem alegar defesa, cientes de que são destituídas de fundamento; IV não produzir provas, nem praticar atos inúteis ou desnecessários à declaração ou defesa do direito. $\mathrm{O}$ art. 16 estabelece que "responde por perdas e danos aquele que pleitear de má-fé como autor, réu ou interveniente." $\mathrm{E}$ o art. 17 define os atos que individuam o litigante de má-fé.

36. Liebman, em Chiovenda, Instituições, v. II, n. 233, nota 1.

37. Liebman, em ChIovenda, Instituições, v. II, n. ${ }^{\circ} 271$, nota 10. 
23. O estudo dos poderes do juiz e a determinação dos seus limites, sobre ser um dos temas fundamentais do direito processual civil, serve também para apreciar a tendência política do Estado, ou como regime totalitário, ou como sistema democrático de garantia de direitos individuais. É que, sendo o juiz, como órgão do Estado, parte integrante da relação processual, pode o Código conferir-lhe atribuições tais, que importem em sacrificar o princípio dispositivo. Que o juiz seja dominus processi, cabendo-lhe o controle, até de ofício, dos pressupostos processuais e das condições de admissibilidade da ação, parece ponto pacífico na legislação e na doutrina dos países democráticos. O processo é uma instituição de direito público destinada à administração da justiça. Ele não pode ser utilizado para fins contrários ao direito, à ética e à justiça. A concepção publicística, que se funda na autoridade do Estado como parte integrante da relação jurídica processual, justifica a ampliação dos poderes do juiz. Mas o mérito do legislador está em estabelecer uma real harmonia entre o princípio dispositivo e o fortalecimento da autoridade judicial. LIEBMAN fez a tal respeito ponderações judiciosas, procurando conciliar as duas tendências antagônicas ${ }^{38}$.

24. O Código de Processo Civil vigente realiza o equilíbrio entre as partes. Com efeito, compete ao juiz dirigir o processo, assegurando às partes igualdade de tratamento, velando pela rápida solução do litígio e prevenindo ou reprimindo qualquer ato contrário à dignidade da justiça (art. 125). Aí estão três princípios cardiais do novo sistema. À parte cabe a iniciativa de ajuizar a ação; este poder é, de sua natureza, pessoal e indisponível, sendo defeso ao Estado subrogar-se nele ou expropriá-lo. Mas, uma vez proposta a ação, o impulso de promover os atos que formam a relação processual fica a cargo do juiz, sem prejuízo do interesse que tem a parte de ativar o andamento célere do processo, para o que está habilitada a requerer as providências que se destinam a esse fim.

Incumbe ao juiz assegurar às partes igualdade de tratamento. Tudo quanto entende com a lide, que é objeto do processo, pertence às partes; por isso é defeso ao juiz julgar tanto ultra ou extra petita (arts. 128, 459 e 460), como subrogar-se à parte na colheita e formação do material probatório quando ela, a quem toca o onus probandi, deixa de produzir a prova no prazo e forma legais. Nada obsta, porém, a que o juiz,

38. Liebman, em Chiovenda, Instituiçōes, v. II, n..$^{\circ} 261$, nota 9. 
para formar o seu convencimento, ordene a realização de perícia, proceda à inspeção pessoal, determine o comparecimento das partes, bem como a exibição de documento ou coisa, ou se sirva de máximas de experiência.

25. E, finalmente, tem o juiz o dever de prevenir ou reprimir qualquer ato contrário à dignidade da justiça. A administração da justiça é uma das atividades primordiais do Estado, exercida pelo Poder Judiciário. Pela nobreza de sua função e pela relevante tarefa de pacificação social, não pode a lei tolerar, por certo, que o litigante impunemente desdenhe a autoridade dos seus julgados, conspire para retardar a marcha do processo ou use de artifícios fraudulentos para obstar a satisfação dos direitos. O Código de Processo Civil arma o juiz de poderes excepcionais para coibir os atos atentatórios à dignidade da justiça. Como estes ocorrem com mais freqüência no processo de execução, enumera alguns deles no art. 600: "Considera-se atentatório à dignidade da justiça o ato do devedor que: I - frauda a execução; II — se opõe maliciosamente à execução, empregando ardis e meios artificiosos; III resiste injustificadamente às ordens judiciais; IV — não indica ao juiz onde se encontram os bens sujeitos à execução."

$\mathrm{O}$ direito de atuar no processo civil tem por limite o respeito ao Poder Judiciário, não se adequando à sua dignidade a prática de ato que tenda a diminuir-lhe o prestígio, a dificultar-lhe o cumprimento das sentenças ou a embaraçar maliciosamente a execução. Reage o Poder Judiciário a tais manifestações, começando por advertir o litigante e terminando por vedar que requeira ou pratique no processo quaisquer atos, enquanto lhe não for relevada a pena ${ }^{39}$.

\footnotetext{
39. Código de Processo Civil, art. 601: "Se, advertido, o devedor perseverar na prática de atos definidos no artigo antecedente, o juiz, por decisão lhe proibirá que daí por diante fale nos autos. Preclusa esta decisão, é defeso ao devedor requerer, recorrer ou praticar no processo quaisquer atos, enquanto não lhe for relevada a pena." O eminente Prof. Alcides DE Mendonça Lima manifesta sua repulsa ao referido dispositivo legal, prognosticando que "se tornará letra morta, porque muito exige." (Alcides DE MendonçA Lima, Comentários ao Código de Processo Civil, v. VI, t. II, p. 555). E mais adiante observa que "até de inconstitucionalidade foi tachado, porque pode subtrair o direito de defesa, desde que, de certo modo, é incontrolável a decisão do juiz." (Ob. cit., p. 556). A ilustre professora ADA PELEGrini Grinover argúi-lhe desenganadamente a inconstitucionalidade, por entender que ele retira ao devedor o direit? ao contraditório (ADA PELEGRINI GRINover, Os Princípios Constitucionais $e$ Código de Processo Civil, p. 123). As críticas feitas ao novo instituto, a nosso ver, não procedem. Os consagrados processualistas não apontam a norma constitucional que teria sido violada; limitam-se a argumentar que a sanção imposta
} 
26. Raros institutos sofreram, através dos tempos, alterações tão sensíveis e substanciais como a revelia. No primitivo direito romano era necessário o comparecimento das partes em juízo para a instauração regular do processo civil. Como, entretanto, nem sempre isso era possível, ou por fuga do réu ou por outra causa, o direito romano impôs graves sanções ao revel. O pressuposto lógico dessa solução legal era a obrigação, que tinha o réu, de estar em juízo quando citado ${ }^{40}$.

0 rigor deste princípio foi abrandado mais tarde, quando em Portugal as Ordenações Filipinas (Liv. III, Tit. 15 e Tit. 20) admitiram que o réu, sendo revel, era havido como se contestasse a ação por negação geral, prosseguindo o processo em seu desenvolvimento normal. A tendência mais recente atribuiu à revelia, em geral, o efeito de se reputarem verdadeiras as

no art. 601 cerceia o direito de defesa. Ora, a norma legal citada não subtrai ao devedor o direito de defesa; subordina-o aos princípios que regem o processo de execução. Com efeito, há diferença substancial entre o processo de conhecimento e o processo de execução. Enquanto no processo de conhecimento vige - princípio da igualdade entre os contendores, porque até a sentença ainda não se sabe qual deles tem razão, no processo de execução, ao contrário, o credor tem uma posição de preeminência, assegurada pela eficácia do título, a que corresponde a parte debitoris um estado de sujeição. No processo de execução, o devedor não se defende, impugna; não contesta, embarga; não se limita a contradizer, propõe uma ação. Realmente, os embargos, que são o instrumento do devedor contra a execução, constituem o exercício de uma ação, que abre um juízo de mérito e se encerra normalmente com a sentença que a acolhe ou a rejeita. Ora, se o devedor frauda a execução, se a ela se opõe maliciosamente, empregando ardis e meios artificiosos, se resiste injustificadamente às ordens judiciais ou se não indica ao juízo onde se encontram os bens sujeitos à execução, - o seu ato, sobre ser ilícito, constitui atentado à dignidade da justiça. certo que no processo de execução nāo tem o devedor obrigação de cooperar com o juízo, mas também não tem o direito de obstar de má fé à realização das providências que tendem à satisfação do pedido do credor. A prática dos atos definidos no art. 600 representa desdém à autoridade judiciária, menosprezo à majestade da justiça e grave ofensa à ordem jurídica institúda pelo Estado. Tolerá-los seria condescender com a fraude, capitulando-se de direito de defesa a resistência ilegítima do devedor. A sanção imposta pelo art. 601, só após a advertência ao devedor, não é, pois, avessa a nenhum canon da Constituição e não tem, portanto, eiva de inconstitucionalidade. Por outro lado, a decisão do juiz, a que alude o art. 601, pode ser impugnada por agravo de instrumento e fica assim sujeita ao duplo grau de jurisdição. Logo está também sob o controle do Tribunal.

40. Ver: MAX KaSER, Das römische Zivilprozessrecht, Munique, 1966, p. 371 e segs.; Wenger, Istituzioni di Procedura Civile Romana, trad. it. de RICARDo Orestano, Giuffrè, 1938, p. 201 e seg.; Emilio Costa, Profilo storico del Processo Civile Romano, p. 101 e segs.; CALMON DE PAssos, Da Revelia do Demandado, Imprensa Oficial da Bahia, Salvador, 1960, p. 21 e seg.; Rogérto Lauria Tuccr, Da Contumácia no Processo Civil Brasileiro, São Paulo, 1964, p. 19 e segs. Rispoli, Il Processo Civile, Contmaciale, Soc. E. Lib. 1911, p. 1 e segs. 
afirmações dos fatos constantes da petição inicial ${ }^{41}$. Tem o réu, conforme esta orientação de política legislativa, o ônus de contestar a ação; e, não o fazendo, há de imputar-se a si próprio o possível insucesso na causa. Não tem, pois, obrigação de contestar, porque a esta idéia não corresponde nenhum direito do autor ; tem, diversamente, um ônus, a que corresponde $o$ risco de perder a demanda.

27 Ao analisar a revelia no Código de Processo Civil de 1939, observou LIEBMAN que "estranhamente escasso é o Código em disposições atinentes à revelia e isto explica as vacilações de seus intérpretes ${ }^{42}$. 0 Código de Processo Civil vigente tratou com largueza desta matéria. Dispõe o art. 319: "Se o réu não contestar a ação, reputar-se-ão verdadeiros os fatos afirmados pelo autor." E no art. 320: "A revelia não induz, contudo, o efeito mencionado no artigo antecedente: I — se, havendo pluralidade de réus, algum deles contestar a ação; II - se o litígio versar sobre direitos indisponíveis; III - se a petição inicial não estiver acompanhada do instrumento público, que a lei considere indispensável à prova do ato."

A revelia exime ao autor o ônus de provar os fatos alegados, porque são havidos por verdadeiros. Mas, para que o juiz admita a revelia, impôs o Código a observância de certas regras: a) do mandado de citação há de constar a advertência ao réu de que, não sendo contestada a ação, se presumirão verdadeiros os fatos articulados pelo autor (arts. 232, V 285) b) a revelia não induz o efeito mencionado no art. 319, ocorrendo qualquer das hipóteses indicadas nos números I, II e III do art. 320 ; c) compete ao juiz verificar se ocorreu a revelia, caso em que conhecerá diretamente do pedido, proferindo sentença de mérito (art. 330, II) ; d) ainda que se verifique a revelia, é defeso ao autor alterar o pedido e a causa de pedir, ou requerer ação declaratória incidental, salvo promovendo nova citação do réu, a quem será assegurado o direito de responder no prazo de quinze dias (art. 321).

28. Uma das mais importantes contribuições de LIEBMAN para o direito processual civil foi, sem dúvida, a revisão do conceito de coisa julgada. A sua doutrina demonstra que a coisa julgada não é um efeito da sentença, como pretendem os autores, mas sim modo de manifestar-se e produzir-se dos efeitos da própria sentença, algo que a esse efeito se ajunta

41. Código de Processo Civil, art. 483, 1.

42. Liebman, em ChIovenda, Instituicões, v. III, n. ${ }^{\circ} 351$, nota 1. 
para qualificá-los e reforçá-los em sentido bem determinado. Incidem todas as definições correntes no erro de substituir uma qualidade dos efeitos da sentença por um efeito seu autônomo ${ }^{43}$. Depois de analisar as várias teorias, conclui definindo a coisa julgada como a imutabilidade do comando emergente da sentença. Não se identifica ela com a definitividade e infungibilidade do ato que pronuncia o comando; é, pelo contrário, uma qualidade mais intensa e mais profunda, que reveste o ato também em seu conteúdo e torna assim imutáveis, além do ato em sua existência formal, os efeitos quaisquer que sejam do próprio ato ${ }^{44}$.

Pois bem. O conceito de coisa julgada material, no Código de Processo Civil vigente, se ajusta à doutrina de LIEBMan: "Art. 467. Denomina-se coisa julgada material a eficácia, que torna imutável e indiscutível a sentença, não mais sujeita a recurso ordinário ou extraordinário." Emprega aí o Código a palavra eficácia no sentido de qualidade ou modo de se manifestarem ou se produzirem os efeitos da própria sentença; ou, em outras palavras, tendo a sentença um comando, a sua imutabilidade identifica-se com a eficácia do efeito declarado naquele ato.

29. Em nota que apôs à edição brasileira da Eficácia e Autoridade da Sentença, observou LiEBMAN que "a questão dos limites objetivos da coisa julgada é uma das mais controvertidas no direito brasileiro" ${ }^{45}$. Tem prevalecido, no entanto, o entendimento de PaUla Batista e JoÃo MEndes Júnior, segundo os quais a coisa julgada é restrita à parte dispositiva do julgamento ${ }^{46}$, não abrangendo nem os motivos nem as questões prejudiciais. LIEBMAN ensinou que "não se abrangem na coisa julgada, ainda que discutidas e decididas, as questões que, sem constituir objeto do processo em sentido estrito, o juiz deverá examinar como premissa da questão principal" ${ }^{4} 7$

Perfilhando esta lição, estatui o Código de Processo Civil vigente: "Art. 469. Não fazem coisa julgada: I — os motivos, ainda que importantes para determinar o alcance da parte dis-

43. Liebman, Eficácia e Autoridade da Sentença, n. ${ }^{\circ} 9$.

44. Liebman, Eficácia e Autoridade da Sentença, n. ${ }^{\circ} 15$.

45. Liebman, Eficácia e Autoridade da Sentença, p. 52, nota 1.

46. Paula Batista, Compêndio de Teoria e Prática do Processo Civil, § 185; JoÃo Mendes JúnIoR, Direito Judiciário Brasileiro, 3. ${ }^{\text {a }}$ ed., Rio de Janeiro, 1940, p. 485 e seg..

47. Liebman, Eficácia e Autoridade da Sentença, p. 53. 
positiva da sentença; II - a verdade dos fatos, estabelecida como fundamento da sentença; III - a apreciação da questão prejudicial, decidida incidentemente no processo." A coisa julgada é, pois, circunscrita à parte dispositiva da sentença, em que o juiz acolhe ou rejeita, no todo ou em parte, o pedido formulado pelo autor (Código de Processo Civil, art. 459). Só fazem coisa julgada, assim, as sentenças que decidem a lide, isto é, as que julgam o mérito da causa. "As decisões que", acentua LIEBMAN, "embora pondo fim ao processo, não lhe resolvem o mérito, tornam-se sem dúvida imutáveis depois de decorridos os prazos para interposição dos recursos; não produzem, porém, a autoridade da coisa julgada." ${ }^{48}$.

\section{Conclusão.}

Já é tempo de concluir. Este ensaio não tem a pretensão de ser uma análise crítica da doutrina do Mestre; escrito sob emoção, é o testemunho vivo do discípulo que desde 1941, haurindo-lhe de contínuo as lições, aprendeu a venerá-lo como homem, como professor e como Mestre do direito processual civil. $\mathrm{E}$, decorridos vinte anos do magistério, teve o discípulo a honra de ser convidado, pelo Ministro da Justiça, dr. Oscar Pedroso Horta, a elaborar o Anteprojeto de Código de Processo Civil, cujo texto entregou em 1964. Esse documento, revisto anos mais tarde por uma Comissão, constituída pelos eminentes juristas José Carlos MoReira Alves, Luís ANTônIo dE ANDRADE, JosÉ FrEDERICo Marques e CÂNDIDo Dinamarco, foi encaminhado ao Congresso Nacional, em mensagem do Presidente da República, a 2 de agosto de $1972^{49}$. Discutido e aprovado nas duas Casas do Congresso, foi sancionado como Lei $n^{\circ} 5.869$, a 11 de janeiro de 1973. Este Código de Processo Civil é um monumento imperecível de glória a LIEBMAN, representando o fruto do seu sábio magistério no plano da política legislativa ${ }^{50}$.

48. Liebman, Eficácia e Autoridade da Sentença, p. 57.

49. Diário do Congresso Nacional n. ${ }^{\circ} 99,28$ de setembro de 1972, p. 69 e segs.

50. A influência de Liebman no Direito Processual Civil brasileiro prossegue, a partir de 1958, dirigindo e orientando uma nova geração de jovens processualistas que, em "corsi singoli", freqüentaram as aulas do Mestre na Universidade de Milão e foram recebidos com toda a hospitalidade em sua casa durante o tempo de seu estágio. Desta plêiade de novos processualistas fazem parte: 1) CÂndido Dinamarco; 2) Ivan O. Roghi; 3) Antonio Celso C. Ferraz; 4) Antônio Aroldo F. da Pozzo; 5) Hans Carlos G. Seligson; 6) JoAQUim Munhoz DE MELlo; 7) José ChizzotTt. 